\title{
Determinan Perilaku Perawatan Kehamilan
}

\author{
Determinant of Mother's Prenatal Care Behaviour
}

Elviera Gamelia, Colti Sistiarani, Siti Masfiah

\section{Jurusan Kesehatan Masyarakat Fakultas Kedokteran dan Ilmu-ilmu Kesehatan Universitas Jenderal Soedirman}

\begin{abstract}
Abstrak
Strategi pembangunan kesehatan nasional adalah untuk mewujudkan peningkatan status derajat kesehatan. Indikator derajat kesehatan masyarakat terkait erat dengan Angka Kematian Ibu (AKI). Kabupaten Banyumas memiliki AKI di bawah standar pelayanan minimal (SPM), salah satunya adalah wilayah kerja Puskesmas I Ajibarang. Peningkatan status kesehatan ibu pada saat kehamilan merupakan salah satu langkah yang dapat dilakukan untuk menurunkan kasus kematian ibu. Status kesehatan ibu hamil dipengaruhi oleh perawatan kehamilan yang baik oleh ibu hamil untuk mencegah terjadinya komplikasi dan kematian ketika persalinan, di samping itu juga untuk pertumbuhan dan kesehatan janin. Penelitian ini bertujuan untuk mengetahui faktor-faktor apakah yang dominan mempengaruhi perilaku perawatan kehamilan. Penelitian ini adalah potong lintang. Populasi adalah seluruh ibu hamil di Puskesmas I Ajibarang. Metode sampel yang digunakan adalah metode proportional random sampling dengan jumlah sampel 81 ibu hamil. Analisis data yang digunakan adalah analisis univariat dengan statistik deskriptif, analisis bivariat dengan kai kuadrat, serta analisis multivariat dengan regresi logistik. Hasil penelitian menunjukkan pendidikan, jenis pekerjaan, pendapatan, paritas, pengetahuan, sikap, dan peran bidan tidak berpengaruh terhadap perilaku perawatan kehamilan. Sedangkan, usia kehamilan, waktu tempuh pelayanan kesehatan, dan peran suami berpengaruh terhadap perilaku perawatan kehamilan. Peran suami merupakan variabel yang paling dominan memengaruhi ibu hamil dalam melakukan perawatan kehamilan.
\end{abstract}

Kata kunci: Ibu hamil, peran suami, perawatan kehamilan

\section{Abstract}

National health strategy is to realize the increasing level of health status. Public health status indicators closely related to Maternal Mortality Rate (MMR). Banyumas have MMR that is still below the minimum service standards. One that contributes to that number is Puskesmas I Ajibarang. Improving the health status of the mother during pregnancy is one of steps taken to reduce maternal deaths. Health status of pregnant women are affected by good prenatal care, preventing the occurrence of complications, death when delivery, the growth and health of the fetus. This study aims to determine the dominant factors influence to behavior of prenatal care in Ajibarang I Primary Health Center, Banyumas District. It was a cross sectional survey. Data was taken by interviews, involved 81 pregnant women in Ajibarang I primary health care. Data analysis used univariate analysis with descriptive statistic, bivariate with chi square and multivariate with logistic regression. The results showed that age, education, family income, occupation, knowledge, attitude, parity, and role of midwives did not influence to prenatal care behaviour. Otherwise, age of pregnancy, time of access to heath care, and role of husbands influenced pregnant women in prenatal care behaviour. Study also found that role of husband was the most dominant factor influenced to mother's prenatal care behaviour.

Keyword: Pregnant women, role of husband, prenatal care behaviour

\section{Pendahuluan}

Indikator derajat kesehatan masyarakat salah satunya diukur dari Angka Kematian Ibu (AKI) dan Angka Kematian Bayi (AKB). ${ }^{1}$ AKI secara nasional pada tahun 2007 adalah 228 per 100.000 kelahiran hidup, sementara itu AKB sebesar 34 per 1.000 kelahiran hidup. Diharapkan pada tahun 2015 AKI dapat ditekan hingga 102 per 100.000 kelahiran hidup dan AKB mencapai 23 per 1.000 kelahiran hidup. ${ }^{1}$ AKI di Jawa Tengah tahun 2011 telah mencapai 116 per 100.000 kelahiran hidup. Data dari Dinas Kesehatan Jawa Tengah tercatat 501 orang ibu bersalin mengalami kematian, sedangkan pada

Alamat Korespondensi: Elviera Gamelia, Jurusan Kesehatan Masyarakat FKIK Universitas Jenderal Soedirman, Jl. dr. Soeparno Kampus Unsoed

Karangwangkal Gd. B, Hp.08562274737, e-mail:viera_gamelia@yahoo.com 
tahun 2012 jumlah kematian ibu bersalin mencapai 611 orang. ${ }^{2}$

Data yang didapatkan dari Dinas Kesehatan Kabupaten Banyumas tahun 2011 termasuk urutan ke-3 memiliki AKI terbesar di provinsi Jawa Tengah, AKI sebesar 140,21 per 100.000 kelahiran hidup, sedangkan AKB sebesar 10,84 per 1.000 kelahiran hidup. Data tersebut meningkat jika dibandingkan dengan data tahun 2012, AKI berada pada kisaran 116,81 per 100.000 kelahiran hidup, sedangkan kematian bayi pada tahun 2012 dilaporkan sebanyak 123 orang, jumlah ini meningkat dibandingkan tahun 2009, jumlah kematian bayi mencapai 107 orang. ${ }^{3}$

Perawatan kehamilan ini merupakan salah satu faktor yang amat perlu diperhatikan untuk mencegah terjadinya komplikasi dan kematian ketika persalinan, di samping itu juga untuk pertumbuhan dan kesehatan janin. ${ }^{4}$ Perawatan kehamilan yang perlu diperhatikan adalah yaitu perawatan diri (kulit, gigi mulut, perawatan ku$\mathrm{ku}$ ) payudara, imunisasi, senam hamil, pemeriksaan kehamilan, serta gizi untuk perkembangan janin. ${ }^{4}$ Perawatan kehamilan dipengaruhi oleh faktor predisposing, faktor pendukung dan faktor faktor penguat, seperti pengetahuan yang diperoleh melalui pemahaman tentang perawatan kehamilan. ${ }^{5}$ Beberapa faktor yang turut berpengaruh di antaranya usia, pendidikan, pekerjaan, paritas, dukungan keluarga, dan ekonomi.

Wilayah kerja Puskesmas Ajibarang I merupakan wilayah dengan jumlah kematian maternal tertinggi di wilayah Kabupaten Banyumas. ${ }^{6}$ Berdasarkan data sekunder Puskesmas Ajibarang didapatkan salah satu indikator perawatan kehamilan adalah pemeriksaan kehamilan yang meliputi cakupan K1 dan K4 masih rendah di Wilayah Kerja Puskesmas I Ajibarang masih di bawah standar pelayanan minimal (SPM). Cakupan K1 di Puskesmas Ajibarang sebesar 97,87 \% masih di bawah SPM yang seharusnya $100 \%$, sedangkan untuk cakupan K4 sebesar $89 \%$ masih di bawah SPM yang seharusnya 95\%.6 Penelitian ini bertujuan untuk mengetahui faktor-faktor yang dominan berpengaruh terhadap perilaku perawatan kehamilan ibu hamil di wilayah kerja Puskesmas Ajibarang I Kabupaten Banyumas.

\section{Metode}

Jenis penelitian yang dilakukan adalah penelitian survei. Pendekatan penelitian ini mengunakan pendekatan potong lintang. Variabel yang diamati meliputi variabel bebas yang terdiri dari pendapatan, usia, paritas, pendidikan, waktu tempuh pelayanan kesehatan, pengetahuan, sikap, peran suami dan peran bidan, sedangkan variabel terikat adalah perilaku perawatan kehamilan. Populasi dalam penelitian ini adalah ibu hamil di wilayah kerja Puskesmas I Ajibarang. Dengan perhitungan sampel proportional random sampling didapatkan jumlah sampel minimal sebesar 81 orang. Dari perhitungan sampel per desa secara proporsional didapatkan hasil, yaitu Desa Ajibarang Kulon sebanyak 26 ibu hamil, Desa Ajibarang Wetan sebanyak 19 ibu hamil, Desa Kracak sebanyak 26 ibu hamil, dan Desa Ciberuk sebanyak $10 \mathrm{ibu}$ hamil. Pemilihan sampel tingkat desa dilakukan secara acak. Pengumpulan data dilakukan dengan menggunakan kuesioner dengan metode wawancara. Analisis data yang digunakan adalah analisis univariat dengan statistik deskriptif, analisis bivariat dengan kai kuadrat, serta analisis multivariat dengan regresi logistik.

\section{Hasil}

Karakteristik responden menunjukkan bahwa sebagian besar ibu hamil berusia 20 - 35 sebanyak $79 \%$ dengan pendidikan $(50,6 \%)$ responden berpendidikan dasar, (84\%) responden tidak bekerja, $(56,8 \%)$ responden memiliki pendapatan tinggi. Usia kehamilan responden sebagian besar trimester II $(51,9 \%)$, trimester III $(38,3)$ sedangkan paling sedikit trimester I $(9,9 \%)$. Paritas dari responden paling banyak adalah Nulipara $(39,5 \%)$ (Tabel 1).

Perilaku perawatan kehamilan yang diukur merupakan tindakan yang dilakukan ibu dalam menjaga kesehatannya meliputi perilaku perawatan diri (meliputi mandi, memotong kuku, membersihkan organ intim, dan menggosok gigi), pemeriksaan kehamilan, pengelolaan nutrisi, perawatan payudara, senam hamil, olah raga, dan istirahat yang cukup.

Analisis univariat menunjukkan bahwa sebagian besar $(51,9 \%)$ responden memiliki pengetahuan tinggi, dan responden yang memiliki pengetahuan rendah $(48,1 \%)$. Sebagian besar $(59,3 \%)$ responden memiliki sikap yang

Tabel 1. Karakteristik Responden

\begin{tabular}{llll}
\hline Karakteristik & Kategori & n & $\%$ \\
\hline Usia & $<20$ tahun & 6 & 7,4 \\
& $20-35$ tahun & 64 & 79,0 \\
Pendidikan & T5 tahun & 11 & 13.6 \\
& Tidak tamat SD & 2 & 2,5 \\
& Dasar & 41 & 50,6 \\
Pekerjaan & Menengah & 31 & 38,3 \\
& Tinggi & 7 & 8,6 \\
& Tidak bekerja & 68 & 84,0 \\
PNS & 2 & 2,5 \\
\multirow{3}{*}{ Pendapatan } & Pegawai swasta & 3 & 3,7 \\
& Petani & 1 & 1,2 \\
& Buruh & 3 & 3,7 \\
Psia kehamilan & Lainnya & 4 & 4,9 \\
& Rendah & 35 & 43,2 \\
& Tinggi & 46 & 56,8 \\
& Trisemester I & 8 & 9,9 \\
& Trisemester II & 42 & 51,9 \\
& Trisemester III & 31 & 38,3 \\
& Nulipara & 32 & 39,5 \\
& Primipara & 26 & 32,1 \\
& Multipara & 23 & 28,4 \\
\hline \multirow{3}{*}{ Paritas } & & &
\end{tabular}


baik, dan responden yang memiliki sikap kurang baik $(40,7 \%)$. Sebagian besar $(59,3 \%)$ responden memiliki peran suami yang baik, dan responden yang memiliki peran suami yang kurang baik $(40,7 \%)$. Sebagian besar $(67,9 \%)$ responden memiliki persepsi peran bidan baik, dan responden memiliki persepsi peran bidan kurang baik $(32,1 \%)$. Sebagian besar responden $(45,7 \%)$ memiliki waktu tempuh sekitar 10 menit untuk ke tempat pelayanan kesehatan. Sebagian besar $(69,1 \%)$ responden memiliki perilaku perawatan kehamilan baik, dan sisanya $(30,9 \%)$ memiliki perilaku perawatan kurang baik (Tabel 2).

Faktor-faktor yang berhubungan dengan perilaku perawatan kehamilan ibu hamil di wilayah Puskesmas I Ajibarang dianalisis secara bivariat. Variabel bebas yang digunakan adalah karakteristik responden (meliputi pendidikan ibu, jenis pekerjaan ibu, pendapatan keluarga, usia kehamilan, paritas, waktu tempuh ke pelayanan kesehatan), kemudian variabel pengetahuan ibu tentang perawatan kehamilan, sikap ibu terhadap perawatan kehamilan, peran bidan dalam perawatan kehamilan, peran suami dalam perawatan kehamilan (Tabel 3).
Analisis multivariat menunjukkan bahwa variabel yang berhubungan secara bermakna terhadap perilaku perawatan kehamilan ibu di wilayah Puskesmas I Ajibarang adalah usia (trimester) kehamilan ibu, waktu tempuh ke tempat pelayanan kesehatan, dan peran suami. Hasil analisis didapatkan ibu hamil dengan usia kehamilan lebih tua tiga kali lebih besar kemungkinan-

Tabel 2. Analisis Univariat

\begin{tabular}{llll}
\hline Variabel & Kategori & n & $\%$ \\
\hline Pengetahuan & Rendah & 42 & 51,9 \\
Sikap & Tinggi & 39 & 48,1 \\
& Kurang baik & 33 & 40,7 \\
Peran suami & Baik & 48 & 59,3 \\
& Kurang baik & 33 & 40,7 \\
Peran bidan & Baik & 8 & 59,3 \\
& Kurang baik & 26 & 32,1 \\
Waktu tempuh ke & Baik & 55 & 67,9 \\
pelayanan kesehatan & 5 menit & 20 & 24,7 \\
& 10 menit & 37 & 45,7 \\
Perilaku perawatan & 10 - 30 menit & 22 & 27,2 \\
kehamilan & Kurang baik & 2 & 2,5 \\
& Baik & 25 & 30,9 \\
& & 56 & 69,1 \\
\hline
\end{tabular}

Tabel 3. Analisis Bivariat Perilaku Perawatan Kehamilan Ibu

\begin{tabular}{|c|c|c|c|c|c|c|}
\hline \multirow{3}{*}{ Variabel } & \multirow{3}{*}{ Kategori } & \multicolumn{4}{|c|}{ Perilaku Perawatan Kehamilan } & \multirow{3}{*}{ Nilai p } \\
\hline & & \multicolumn{2}{|c|}{ Kurang Baik } & \multicolumn{2}{|c|}{ Baik } & \\
\hline & & $\mathbf{n}$ & $\%$ & $\mathbf{n}$ & $\%$ & \\
\hline \multirow[t]{4}{*}{ Pendidikan ibu } & Tidak tamat SD & 0 & 0,0 & 2 & 100 & 0,566 \\
\hline & Dasar & 14 & 34,1 & 27 & 65,9 & \\
\hline & Menengah & 10 & 32,3 & 21 & 67,7 & \\
\hline & Tinggi & 1 & 14,3 & 6 & 85,7 & \\
\hline \multirow[t]{6}{*}{ Jenis pekerjaan } & Tidak bekerja & 23 & 33,8 & 45 & 66,2 & 0,695 \\
\hline & PNS & 0 & 0,0 & 2 & 100 & \\
\hline & Pegawai swasta & 0 & 0,0 & 3 & 100 & \\
\hline & Petani & 0 & 0,0 & 1 & 100 & \\
\hline & Buruh & 1 & 25,0 & 3 & 75,0 & \\
\hline & Lainnya & 1 & 33,3 & 2 & 66,7 & \\
\hline \multirow[t]{2}{*}{ Pendapatan keluarga } & Rendah $(<785.000)$ & 13 & 37,1 & 22 & 62,9 & 0,205 \\
\hline & Tinggi $(\geq 785.000)$ & 12 & 26,1 & 34 & 73,9 & \\
\hline Usia (trimester) & Trisemester I & 5 & 62,5 & 3 & 37,5 & $0,025^{*}$ \\
\hline \multirow[t]{2}{*}{ kehamilan } & Trisemester II & 15 & 35,7 & 27 & 64,3 & \\
\hline & Trisemester III & 5 & 16,1 & 26 & 83,9 & \\
\hline \multirow[t]{3}{*}{ Paritas } & Nulipara & 13 & 40,6 & 19 & 59,4 & 0,184 \\
\hline & Primipara & 8 & 30,8 & 18 & 69,2 & \\
\hline & Multipara & 4 & 17,4 & 19 & 82,6 & \\
\hline \multirow{4}{*}{$\begin{array}{l}\text { Waktu tempuh ke } \\
\text { pelayanan kesehatan }\end{array}$} & 5 menit & 12 & 60,0 & 8 & 40,0 & $0,01^{* * *}$ \\
\hline & 10 menit & 8 & 21,6 & 29 & 78,4 & \\
\hline & $10-30$ menit & 4 & 18,2 & 18 & 81,8 & \\
\hline & $>30$ menit & 1 & 50,0 & 1 & 50,0 & \\
\hline \multirow[t]{2}{*}{ Pengetahuan } & Rendah & 12 & 28,6 & 30 & 71,4 & 0,412 \\
\hline & Tinggi & 13 & 33,3 & 26 & 66,7 & \\
\hline \multirow[t]{2}{*}{ Sikap } & Kurang baik & 12 & 36,4 & 21 & 63,6 & 0,259 \\
\hline & Baik & 13 & 27,1 & 35 & 72,9 & \\
\hline \multirow[t]{2}{*}{ Peran bidan } & Kurang berperan & 6 & 23,1 & 20 & 76,9 & 0,218 \\
\hline & Berperan baik & 19 & 34,5 & 36 & 65,5 & \\
\hline \multirow[t]{2}{*}{ Peran suami } & Kurang mendukung & 17 & 51,5 & 16 & 48,5 & 0,001 **** \\
\hline & Mendukung baik & 8 & 16,7 & 40 & 83,3 & \\
\hline
\end{tabular}

Keterangan: *nilai $p \leq 0,05$, **nilai $p \leq 0,01, * * *$ nilai $p \leq 0,001$ 
Tabel 4. Analisis Multiariat Perilaku Perawatan Kehamilan

\begin{tabular}{lllll}
\hline Variabel & Beta & SE & B & Nilai p \\
\hline Pendapatan & 0,499 & 0,610 & 1,647 & 0,413 \\
Usia (trimester) kehamilan & 0,971 & 0,500 & 2,641 & 0,052 \\
Paritas (kelahiran hidup) & 0,740 & 0,404 & 2,096 & 0,067 \\
Waktu tempuh ke & 0,966 & 0,401 & 2,628 & 0,016 \\
pelayanan kesehatan & 1,988 & 0,671 & 7,299 & 0,003 \\
Peran suami & 0,142 & 0,733 & 1,153 & 0,846 \\
Peran bidan & $-6,027$ & 1,907 & 0,002 & 0,002 \\
Konstan & & & & \\
\hline
\end{tabular}

nya untuk melakukan perawatan kehamilan dengan baik. Ibu hamil dengan waktu tempuh ke tempat pelayanan kesehatan lebih sedikit tiga kali lebih besar kemungkinannya untuk melakukan melakukan perawatan kehamilan dengan baik. Ibu hamil yang memiliki suami yang berperan baik dalam mendukung perawatan kehamilan tujuh kali lebih besar kemungkinannya untuk melakukan perawatan kehamilan dengan baik (Tabel 4).

Peran suami merupakan variabel yang paling berpengaruh terhadap perilaku perawatan kehamilan ibu di wilayah Puskesmas I Ajibarang Banyumas. Dalam masyarakat patriarkhi suami berpengaruh terhadap pengambilan keputusan dalam keluarga. Penelitian serupa tentang keterlibatan suami dalam perawatan antenatal menunjukkan bahwa dukungan emosional, intrumental, dan informasi sangat berpengaruh terhadap kesehatan ibu hamil.

\section{Pembahasan}

Hasil penelitian menunjukkan pendidikan tidak berhubungan terhadap perilaku perawatan kehamilan ibu. Penelitian lain yang mendukung hasil temuan ini adalah penelitian di malang, yaitu pendidikan ibu tidak berpengaruh terhadap perilaku perawatan kehamilan (antenatal care). ${ }^{7}$ Hasil penelitian juga menunjukkan jenis pekerjaan tidak berhubungan terhadap perilaku perawatan kehamilan ibu. Beberapa penelitian lain juga menemukan pekerjaan ibu tidak berpengaruh terhadap perawatan kehamilan, pemilihan tempat persalinan. ${ }^{7,8}$ Hasil penelitian selanjutnya menunjukkan pendapatan tidak berhubungan terhadap perilaku perawatan kehamilan ibu. Hasil ini serupa dengan beberapa penelitian lain, pendapatan keluarga tidak berhubungan secara bermakna dengan perilaku perawatan kehamilan ibu. ${ }^{9,10}$

Hasil penelitian menunjukkan bahwa usia/trimester kehamilan berhubungan terhadap perilaku perawatan kehamilan ibu. Semakin tua usia kehamilan ibu, maka ibu semakin peduli terhadap kehamilannya, melakukan perawatan kehamilannya lebih baik. Penelitian di Jepara juga menemukan hal yang serupa, salah satu perilaku perawatan kehamilan yaitu kunjungan ke pelayanan kesehatan dilakukan ibu lebih sering seiring dengan ber- tambahnya usia kehamilan. ${ }^{11}$ Berbagai faktor yang berpengaruh pada kunjungan ibu ke pelayanan kesehatan seiring dengan bertambnya usia kehamilan, salah satu penelitian di Semarang dan Deli menyebutkan beberapa penyakit penyerta kehamilan, seperti Gingivitis dikenali/disadari ibu hamil setelah tingkat keparahan tertentu, biasanya pada usia kehamilan ke-7 dan ke-8, pada kondisi ini mereka akan lebih memperhatikan kehamilannya. Hasil penelitian menunjukkan waktu tempuh untuk menjangkau tempat pelayanan kesehatan merupakan salah satu faktor yang berhubungan dengan perilaku perawatan kehamilan. ${ }^{12}$

Penelitian lain dari data sekunder Riskesdas 2007 juga menunjukkan bahwa waktu tempuh sangat berpengaruh terhadap pemanfaatan pelayanan kesehat-an. Masyarakat yang bisa menjangkau tempat pelayanan kesehatan lebih cepat cenderung memanfaatkan pelayanan kesehatan tersebut lebih besar dari pada masyarakat yang jauh, membutuhkan waktu yang lama untuk menjangkau tempat pelayanan kesehatan. ${ }^{13}$

Pengetahuan sebagai salah satu variabel bebas dikelompokkan menjadi dua kategori, yaitu rendah dan tinggi. Hasil penelitian menunjukkan responden yang memiliki pengetahuan rendah dan memiliki perilaku perawatan kehamilan kurang baik sebesar $(28,6 \%)$ lebih kecil dibandingkan dengan responden yang memiliki pengetahuan tinggi dan memiliki perilaku perawatan kehamilan yang kurang baik $(33,3 \%)$. Uji kai kuadrat menunjukkan nilai $p$ sebesar 0,412 dengan demikian nilai $p$ lebih besar dari alpha 5\% $(0,05)$. Hal ini menunjukkan bahwa tidak ada hubungan yang signifikan antara pengetahuan dengan perilaku perawatan kehamilan. Hasil penelitian ini bertolak belakang dengan penelitian Nisar and White yang menyebutkan bahwa pengetahuan berpengaruh terhadap pemanfaatan antenatal care. ${ }^{14}$ Tidak sesuai juga dengan penelitian Mariam yang menyatakan pengetahuan ibu sangat memengaruhi dalam pelaksanaan antenatal care. ${ }^{15}$

Sikap ibu hamil terhadap perilaku perawatan kehamilan dikelompokkan menjadi dua kategori, yaitu sikap kurang baik dan sikap baik. Hasil penelitian menunjukkan responden yang memiliki sikap kurang baik dan memiliki perilaku perawatan kehamilan yang kurang baik sebesar $(36,4 \%)$ lebih besar dibandingkan dengan responden yang memiliki sikap baik dan memiliki perilaku perawatan kehamilan kurang baik $(27,1 \%)$. Uji kai kuadrat menunjukkan nilai $\mathrm{p}$ sebesar 0,259 , dengan demikian nilai p lebih besar dari alpha 5\%. Hal ini menunjukkan bahwa tidak ada hubungan yang signifikan sikap dengan perilaku perawatan kehamilan. Hasil penelitian ini bertolak belakang dengan hasil penelitian Tanone dan Priyadarsini yang menyebutkan bahwa terdapat hubungan antara sikap dengan kepatuhan kunjungan antenatal care pada ibu primigravida. ${ }^{16}$ 
Peran bidan dalam mendukung perilaku perawatan kehamilan ibu hamil dikategorikan menjadi dua, yaitu kurang baik dan baik. Hasil penelitian menunjukkan responden yang memiliki peran bidan kurang baik dan memiliki perilaku perawatan kehamilan yang kurang baik sebesar $(23,1 \%)$ lebih kecil dibandingkan dengan responden yang memiliki peran bidan baik dan memiliki perilaku perawatan kehamilan kurang baik $(34,5 \%)$. Uji kai kuadrat menunjukkan nilai p sebesar 0,218 dengan demikian nilai $\mathrm{p}$ lebih kecil dari alpha 5\%. Hal ini menunjukkan bahwa tidak ada hubungan yang signifikan peran bidan dengan perilaku perawatan kehamilan. Tenaga bidan desa ini merupakan tenaga kesehatan yang paling dekat dengan masyarakat, serta diharapkan paling mengetahui keadaan kesehatan ibu hamil, ibu bersalin dan bayi di desa. Berdasarkan penelitian Lesiyaningsih, secara umum ibu hamil akan melaksanakan kegiatan sesuai dengan pedoman yang telah ditetapkan dalam buku panduan bidan di tingkat desa, yaitu mereka melakukan pemeriksaan kehamilan dengan standar 5 T. ${ }^{17}$ Penelitian Phillippi menunjukkan bahwa peran tenaga kesehatan berhubungan dalam pemeriksaan kehamilan. ${ }^{18}$

Peran suami dalam terhadap perawatan kehamilan istrinya dikelompokkan menjadi dua kategori, yaitu kurang baik dan baik. Hasil penelitian menunjukkan responden yang memiliki peran suami kurang baik dan memiliki perilaku perawatan kehamilan yang kurang baik sebesar $(51,5 \%)$ lebih besar dibandingkan dengan responden yang memiliki peran suami baik dan memiliki perawatan kehamilan yang kurang baik $(16,7 \%)$. Uji kai kuadrat menunjukkan nilai $\mathrm{p}$ sebesar 0,001 , dengan demikian nilai $\mathrm{p}$ lebih besar dari alpha 5\%. Hal ini menunjukkan bahwa ada hubungan yang signifikan sikap dengan perilaku perawatan kehamilan. Hal tersebut sesuai dengan penelitian Ruslina yang menyatakan ada hubungan antara dukungan suami dalam pemeriksaan kehamilan. ${ }^{19}$ Dukungan suami yang baik dapat memberikan motivasi yang baik kepada ibu dalam memeriksakan kehamilan. Tindakan yang dilakukan oleh suami selama proses kehamilan sampai persalinan bisa dengan mengantar istri untuk pemeriksaan kehamilan, memberikan makanan bergizi untuk istri, mengajak istri untuk melakukan olah raga ringan, membantu mengerjakan tugas sehari-hari, menyiapkan biaya persalinan, ikut memilih tempat bersalin untuk istri, menemani atau mendampingi istri saat melahirkan, dan mengingatkan istri untuk memberikan ASI ekslusif. ${ }^{20}$ Keterlibatan suami sejak awal kehamilan sampai dengan persalinan dan nifas akan meningkatkan perilaku perawatan ibu hamil sehingga menentukan keberhasilan ibu dalam masa kehamilan sampai dengan proses persalinan. ${ }^{21}$

Peran suami merupakan variabel yang paling berpengaruh terhadap perilaku perawatan kehamilan ibu di wilayah Puskesmas I Ajibarang Banyumas. Dalam masyarakat patriarkhi suami berpengaruh terhadap pengambilan keputusan dalam keluarga. Penelitian serupa tentang keterlibatan suami dalam perawatan antenatal menunjukkan bahwa dukungan emosional, intrumental, dan informasi sangat berpengaruh terhadap kesehatan ibu hamil. $22-25$

\section{Kesimpulan}

Peran suami adalah variabel yang paling dominan berhubungan terhadap perilaku perawatan kehamilan dimana ibu yang memiliki suami yang mendukung perawatan kehamilan tujuh kali lebih besar kemungkinannya untuk melakukan perawatan kehamilan dengan baik dibandingkan ibu dengan suami yang tidak berperan dalam perawatan kehamilan.

\section{Daftar Pustaka}

1. Badan Perencanaa dan Pembangunan Nasional (Bappenas). The achievement of the millenium development goals Indonesia 2007. Jakarta: Bappenas; 2007.

2. Dinas Kesehatan Propinsi Jawa Tengah. Laporan kesehatan ibu dan anak. Semarang: Dinas Kesehatan Propinsi Jateng; 2011.

3. Dinas Kesehatan Kabupaten Banyumas. Laporan tahunan kesehatan ibu dan anak. Banyumas: Bidang Penggerakan dan Pelaksanaan Pelayanan Kesehatan; 2012.

4. Pinem S. Kesehatan reproduksi dan kontrasepsi. Jakarta: CV Trans Info Media; 2002.

5. Notoatmodjo S. Pengantar pendidikan kesehatan dan ilmu perilaku kesehatan. Jakarta: Rineka Cipta; 2007.

6. Dinas Kesehatan Kabupaten Banyumas. Profil kesehatan kecamatan Ajibarang tahun 2012. Banyumas: Dinas Kesehatan Kabupaten Banyumas; 2012.

7. Soeparmanto P. Faktor-faktor yang mempengaruhi perilaku perawatan kehamilan (antenatal care (ANC) ibu hamil (studi di wilayah kerja Puskesmas Gondanglegi Kabupaten Dati 1 Malang. Buletin Penelitian Sistem Kesehatan. 1998; 2: 48-57.

8. Devi RS. Perawatan kehamilan dalam perspektif budaya Madura di Desa Tambak dan Desa Rapalaok Kecamatan Omben Kabupaten Sampang. Jurnal Promosi Kesehatan. 2011; 1 (1): 50-62

9. Winarsih. Pendidikan kesehatan mengatasi keluhan hamil pada ibu-ibu hamil di Asrama Group Ii Kopassus Kartasura. Warta. 2006; 9 (2): 107 -2 .

10. Indarwati. Hubungan perilaku ibu dalam memanfaatkan pelayanan kesehatan selama hamil dengan kepatuhan immunisasi pada anak di Sukoharjo. Gaster. 2008; 4 (1): 154-66.

11. Suryawati C. Faktor sosial budaya dalam praktik perawatan kehamilan, persalinan, dan pasca persalinan (studi di Kecamatan Bangsri Kabupaten Jepara). Jurnal Promosi Kesehatan Indonesia. 2007; 2: 21-31.

12. Aritonang I, Manurung KN, Nurasniawati S. Hubungan umur kehamilan ibu dengan keadaan gingivitis di Desa Patumbak I dan II Kecamatan Patumbak Kabupaten Deli Serdang tahun 2012. Medan: Politeknik Kesehatan Kemenkes Medan Jurusan Keperawatan Gigi; 2012.

13. Paramita A, Pranata S. Analisis faktor pemanfaatan polindes menurut konsep model perilaku kesehatan Anderson (analisis lanjut data riskes- 
das 2007). Buletin Penelitian Kesehatan. 2013; 41(3); 179 - 94.

14. Nisar N, White, F. Factors affecting utilization of antenatal care among reproductive age group woman (15-49 years) in an urban squatter Settlement of Karachi. Journal of Pakistan Medical Association. 2008; 53 (2): 2008.

15. Mariam. Faktor-faktor penyebab belum tercapainyacakupan K4 antenatal care di Desa Sukoharjo I wilayah kerja Puskesmas Sukoharjo Kabupaten Tanggamus [skripsi]. Medan: Fakultas Kedokteran Universitas Sumatera Utara; 2006.

16. Ye Y, Yoshida Y, Rashid H, Sakamoto J. Factors affecting the utilization of antenatal care services among women in Kham District, Xiengkhouang Province, Lao Pdr. Nagoya Journal of Medical Science. 2010; 72; 23-33.

17.Lesiyaningsih, E. Karakteristik dan kegiatan bidan desa dalam peningkatan cakupan K1 dan K4 di Kabupaten Brebes [skripsi]. Semarang: Universitas Diponegoro; 1997.

18. Phillippi JC. Women's perception of access to prenatal care in the United States. Journal Midwifery Womens Health. 2009; 54 (3): 219-25.

19. Ruslina A. Hubungan dukungan suami dan motivasi ibu hamil dalam memeriksakan kehamilan antenatal care (ANC) di wilayah Puskesmas
Bathil Dolopo Madiun [skripsi]. Ponorogo: Jurusan Keperawatan Akademi Keperawatan Ponorogo; 2006

20. Mitayani. Asuhan keperawatan maternitas. Jakarta: Salemba Medika; 2009.

21. Musbikin I. Panduan bagi ibu hamil dan melahirkan. Yogyakara: Mitra Pustaka 2005.

22. Story Et Al. Husbands' involvement in delivery care utilization in rural Bangladesh: a qualitative Study. BMC Pregnancy and Childbirth. 2012; 12: 28.

23. Redshaw And Henderson: Fathers' engagement in pregnancy and childbirth: evidence from a national survey. BMC Pregnancy and Childbirth. 2013; $13: 70$.

24. Kura S, Vince J, Crouch-Chivers P. Male involvement in sexual and reproductive health in the Mendi District, Southern Highlands Province Of Papua New Guinea: a descriptive study. Reproduction Health. 2013; 10: 46-56.

25. Adongo PB, Tabsoba P, Phillips JF, Tabong PTN, Stone A, Kuffour E, et al. The role of community-based health planning and service strategy in involving males in the provision of family planning services: a qualitative study in Southern Ghana. Reproductive Health. 2013; 10: 36-51. 